\title{
The Use of Wiki in an Academic Course: A Qualitative Investigation
}

\author{
Noa Aharony \\ Bar Ilan University, Ramat-Gan, Israel \\ aharonn1@mail.biu.ac.il
}

\begin{abstract}
The current research aims to explore and analyze the application and use of a wiki, in a knowledge-management academic course. The research will focus on the level of collaboration among students and on the kind of interaction that takes take place during the learning process. The population of this study was comprised of wiki pages which were gathered from a knowledgemanagement wiki course in Israel. To understand the comments directed at each student on the wiki, a thorough content analysis was conducted. The results of the current research reveal that the major part of the interaction that took place on the wiki centered on content-related comments and contained both collaboration among the students and use of deep levels of cognition.
\end{abstract}

Keywords: wiki, collaboration, interaction, web 2.0, knowledge-management.

\section{Introduction}

Many people talk about Web 2.0. What is this Web 2.0? Is it a revolutionary web? Is it another technology "bubble"? Is it hype? Many associate it with terms such as blogs, wikis, podcasts, RSS feeds, social web, and many others. They assert that Web 2.0 is a place where everyone can add or edit information, where digital tools allow users to create, change, and publish dynamic content (Stephens, 2006).

The current research aims to explore and analyze the application and use of a wiki, which is a key concept of Web 2.0, in a knowledge-management academic course. A wiki is a webpage that can be easily edited by anyone who is allowed to access it (Edersbach, Glaser, \& Heigl, 2006). The wiki is a collaborative tool that facilitates the production of a group work and a tool for building knowledge bases which are dynamic and fluid. Sharing and collaboration are in the spirit of knowledge management, and are associated with improved organizational learning, creation of new knowledge, and knowledge reuse (Hall \& Goody, 2007). A wiki site changes at the will of the participants. People can add and edit web pages without knowing programming or HTML (Dalkir, 2005). Wikis have a history function which allows previous versions to be examined, they are easy to use and flexible (Ebersbach, Glaser, \& Heigl, 2006). To sum, wikis offer a simple

Material published as part of this publication, either on-line or in print, is copyrighted by the Informing Science Institute. Permission to make digital or paper copy of part or all of these works for personal or classroom use is granted without fee provided that the copies are not made or distributed for profit or commercial advantage AND that copies 1) bear this notice in full and 2) give the full citation on the first page. It is permissible to abstract these works so long as credit is given. To copy in all other cases or to republish or to post on a server or to redistribute to lists requires specific permission and payment of a fee. Contact Publisher@InformingScience.org to request redistribution permission. editing and publishing interface that can be used and understood easily (Kille, 2006; Leuf \& Cunningham, 2001; Wagner, 2004). An example of a wiki is Wikipedia which is a free encyclopedia written by thousands of people all over the world.

This research will focus on the level of collaboration among students and on the kind of interaction that takes take place 
during the learning process. The research findings are relevant for anyone who is interested in understanding the impact of implementation new technologies in educational settings.

\section{Literature Review}

As the present research will explore whether the students who have used the wiki in their learning process, were active learners who have constructed new ideas, concepts and hypotheses and were engaged in an active dialogue with their peers as well as with their instructor, the following section will provide a brief introduction to some of the fundamental concepts of the constructivism leaning theory.

\section{Constructivism}

Constructivism is based on the premise that knowledge is not simply absorbed or transferred by the individuals, but that individuals actively construct personally meaningful understandings as they interpret their experiences and ascribe meaning to them (Piaget, 1963; Resnick, 1981; Shuell, 1986). There are several major principles common to most constructivism-based approaches to teaching and learning. The first one is that learning is an active process in which learners construct new ideas or concepts based upon their knowledge. (Harris \& Alexander, 1998; Merrill, 1991). The teacher's role is to assist performance and construction of knowledge rather than provide knowledge or information (Reid, 1993). The second principle that underlies constructivism is that constructivists perceive learning as a social activity (Brooks \& Brooks, 1997).

Since one of the main topics, being discussed in the article is which learning strategies the students have used while working on the wiki: a deep or a surface learning strategy; the next section will deal with deep and surface learning strategies.

\section{Learning Strategies: Deep and Surface}

Marton and Saljo (1976a; 1976b) distinguished between deep learning strategies and surface learning strategies. The distinction is based on the qualitative analysis they performed in order to define the differences in students' approaches to written texts.

The deep-learning strategy is characterized by the ability to relate new information to previously acquired knowledge, to study different aspects of the material in order to obtain the entire picture, and to search for a relevant meaning and a connecting point between the learning material and daily life and personal experiences.

The surface-learning strategy is characterized by a student's tendency to choose the quickest way to accomplish the task, to acquire the necessary information without asking in-depth questions, to study the material in a linear manner; to relate to minimal aspects of material or to a problem without showing interest or need to understand it in its entirely, to learn by rote by relying on memory and not on comprehension, and to be concerned with the time needed to fulfill the learning task (Biggs, 1993).

This research will delve into the level of collaboration among students who used wiki in their academic course and will try to see if this technological platform facilitates collaborative learning and enables students to share knowledge; therefore the following section will focus on the topic of collaborative learning.

\section{Collaborative Learning}

The term CSCL (computer-supported collaborative learning) focuses on how technology can facilitate the sharing and creation of knowledge through peer interaction and group learning processes (Resta \& Laferrière, 2006). The main aim of CSCL is to provide an environment that sup- 
ports collaboration between students to enhance their learning processes (Kreijns, Kirschner, \& Jochems, (2003), to facilitate collective learning (Pea, 1994), or group cognition (Stahl, 2006). The interest in CSCL reflects the emergence of new technological tools (Newman, Johnson, Webb, \& Cochrane, 1997), as well as the emergence of constructivist approaches to teaching and learning (Kirschner, Martens, \& Strijbos, 2004), and the need to create more powerful learning environments (Oblinger \& Oblinger, 2005). Kirschner (2001) asserts that collaborative learning is an active process, where teachers and pupils share experiences, the teacher is a facilitator, and students learn in small groups, reflect on their assumptions and are responsible for their learning.

The technological application, which has been used in the current research was the wiki platform, thus, the following section will introduce the wiki as a learning tool.

\section{Wiki as a Learning Tool}

Various researches focus on the use of wiki as a learning tool in secondary schools. Grant (2006) and Forte and Brukman (2007) who used wikis to support learning, claim that secondary school students did not use the social and cultural practices of collaborative working and that using wikis present barriers to collaboration. Examining wiki use in higher education reveals that wiki technology can help some knowledge- management goals for collaborative work and organizational learning (Fuchs-Kittowski \& Köhler, 2002; Kille, 2006; Wagner, 2004; Wagner, Cheung, \& Rachael, 2006). Raman, Rayn, and Olfman (2005) have conducted a research which examined the use of wiki in facilitating a knowledge-management class in an academic setting. They conclude that wiki enables students and instructors to be in a continuous discussion, and that the wiki can be used as a knowledge repository. Furthermore, they suggest that wikis can support collaborative knowledge creation and sharing in an academic environment. However, success depends on certain variables - familiarity with wiki technology, careful planning for implementation and use, appropriate class size, and motivation of students to engage in discovery learning.

The present research also explores the use and applications of wiki in an academic environment in a knowledge-management course, while focusing on the level of collaboration among students and on the kind of interactions which take place during the learning process. The following questions guided the design and the analysis of this study: What was the level of collaboration among students who participated in the wiki creation and what kind of interaction took place on the wiki? Was it a social, courteous interaction that supported the process of learning, or was it content related, collaborative, and deep, one which contributed substantially to the learning process itself?

\section{Method}

The database on which this research focused was comprised of wiki pages which were gathered from a knowledge-management wiki course in Israel. Because no formal reader was available for the course, the instructor decided to use a wiki platform to create a class reader. The students' final assignment for the course consisted of writing a unit on a specific topic and putting it on the wiki, and of reading, responding, amending, and changing three other units, written by their classmates. The course included 19 undergraduate second-year students who participated in an information-management academic program in the Library and Information Science Department. To understand the comments directed at each student on the wiki, a thorough content analysis was conducted. Each message was divided into units of meaning which compromise the units of analysis. A unit of meaning can be a phrase, a sentence or some sentences which convey one message. 


\section{Findings}

The researcher found 247 messages on the wiki (in the discussion section), of which she analyzed 677 units of analysis. Fifteen categories were defined, which allowed the researcher to classify the appearance of the discussion in an unambiguous manner. For the sake of the analysis, the categories were combined and grouped into four broad categories (Table 1).

Table 1. The four broad categories of the discussion section

\begin{tabular}{|l|c|c|}
\hline \multicolumn{1}{|c|}{ Broad Category } & Number of Units of Analysis & \% \\
\hline 1. Courtesy & 121 & $17.9 \%$ \\
\hline 2. Instructor's comments & 153 & $22.6 \%$ \\
\hline 3. Students' constructive comments & 191 & $28.2 \%$ \\
\hline $\begin{array}{l}\text { 4. Students' response to their class- } \\
\text { mates }\end{array}$ & 212 & $31.3 \%$ \\
\hline
\end{tabular}

The breakdown of the four broad categories into fifteen categories and their descriptions appear in Table 2.

Table 2. The breakdown of the broad categories into sub-categories

\begin{tabular}{|c|c|c|c|}
\hline Broad Category & Sub-category & Number & $\%$ \\
\hline 1. Courtesy & & 121 & $100 \%$ \\
\hline \multirow[t]{4}{*}{ 2. Instructor's comments } & & 153 & $100 \%$ \\
\hline & Supportive comments & 32 & $21 \%$ \\
\hline & Style and bibliography & 52 & $34 \%$ \\
\hline & Substantive comments & 69 & $45 \%$ \\
\hline \multirow{5}{*}{$\begin{array}{l}\text { 3. Students' constructive } \\
\text { comments }\end{array}$} & & 191 & $100 \%$ \\
\hline & $\begin{array}{l}\text { Structure and bibliogra- } \\
\text { phy comments }\end{array}$ & 26 & $13.6 \%$ \\
\hline & Clarification & 31 & $16.2 \%$ \\
\hline & $\begin{array}{l}\text { Expanding the assign- } \\
\text { ment }\end{array}$ & 37 & $19.4 \%$ \\
\hline & Deep comments & 97 & $50.8 \%$ \\
\hline \multirow{7}{*}{$\begin{array}{l}\text { 4. Students' responses to } \\
\text { their classmates }\end{array}$} & & 212 & $100 \%$ \\
\hline & $\begin{array}{l}\text { Communication with the } \\
\text { instructor }\end{array}$ & 17 & $8 \%$ \\
\hline & Emotional reaction & 18 & $8 \%$ \\
\hline & $\begin{array}{c}\text { Technical and structural } \\
\text { comments }\end{array}$ & 19 & $9 \%$ \\
\hline & Appreciation & 31 & $14.6 \%$ \\
\hline & $\begin{array}{l}\text { Direct response to other } \\
\text { students' comments }\end{array}$ & 47 & $22.2 \%$ \\
\hline & $\begin{array}{l}\text { Substantive deep com- } \\
\text { ments }\end{array}$ & 80 & $38 \%$ \\
\hline
\end{tabular}




\section{Discussion and Conclusion}

The main questions which underlined the design and the analysis of this study addressed the level of collaboration among students who participated in the wiki creation and the kind of interaction that took place on the discussion section of the wiki.

Analyzing the content of the categories reveals that the discussion section of the wiki encompasses both content-related (collaborative, deep) comments and courteous, social comments. But, it should be noted that the major part of the discussion centered on comments that were content related and contained both collaboration among the students and use of deep levels of cognition. This finding is interesting and encouraging, as it reflects the profound levels of discussion and interaction, which may take place on the wiki. But, one should remember that even though the wiki is an application that enables deep learning, it is only the first condition for deep learning or interaction. The instructor and the other students should participate, encourage, and maintain this kind of dialogue.

Surprisingly, the students contributed to the wiki only in the discussion section and did not edit or amend the assignment itself. One may assume that because it was the students' first experience with the wiki in a learning context, they did not feel comfortable to correct other students' work, and they preferred to comment only on the discussion section.

Based on the encouraging findings of the current research, the researcher recommends expanding and exploring the use of wiki in more different academic learning contexts. Further research may refer to other aspects of the learning process such as: learners' motivation to participate in the creation of the wiki, or learners' motivation to use any other Web 2.0 application. Another research may examine students' perceptions towards implementing different Web 2.0 applications in their learning process.

\section{Reference}

Biggs, J. (1993). What do inventories of students' learning process really measure? A theoretical review and clarification. British Journal of Educational Psychology, 63, 3-19.

Brooks, Z., \& Brooks, M. (1997). The search after understanding: Towards Constructivist teaching. Israel: Ministry of Education and Bronco Vice Institution. (Hebrew).

Dalkir, K. (2005). Knowledge management in theory and practice. England: Elsevier.

Ebersbach, A., Glaser, M., \& Heigl, R. (2006). Wiki: Web collaboration. Germany: Springer-Verlag.

Forte, A., \& Bruckman, A. (2007). Constructing text: Wiki as a toolkit for (collaborative?) learning. Retrieved February, 19, 2008, from http://www.wikisym.org/ws2007/_publish/Forte_WikiSym2007_ConstructingText.pdf

Fuchs-Kittowski, F., \& Köhler, A. (2002). Knowledge creating communities in the context of work processes. ACM SIGCSE Bulletin, 23(3), 8-13.

Grant. L. (2006). Using Wikis in schools: A case study. Retrieved February 19, 2008, from http://www.futurelab.org.uk/resources/documents/discussion_papers/Wikis_in_Schools.pdf

Hall, H., \& Goody, M. (2007). KM, culture and compromise: Interventions to promote knowledge sharing supported by technology in corporate environments. Journal of Information Science, 33(2), 181-188.

Harris, K. R., \& Alexander, P. A. (1998). Integrated, constructivistic education: Challenge and reality. Educational Psychology Review, 10(2), 115-128.

Henri, F. (1992). Computer conferencing and content analysis. In A. Kaye (Ed), Collaborative learning through computer conferencing: The Najaden papers (pp. 117-136). Berlin: Springer-Verlag. 
Kirschner, P. A. (2001). Using integrated electronic environments for collaborative teaching/learning. Learning and Instruction, 10(Suppl. 1), 1-9.

Kille, A. (2006). Wikis in the workplace: How wikis can help manage knowledge in library reference services. Retrieved April 24, 2 006, from http://libres.curtin.edu.au/libres16n1/Kille_essayopinion.htm

Kirschner, P. A., Martens, R. L., \& Strijbos, J. W. (2004). CSCL in higher education? A framework for designing multiple collaborative environments. In J. W., Strijbos, P. A., Kirschner, \& R. L., Martens (Eds.), What we know about CSCL: And implementing it in higher education (pp. 3-30). Boston, MA: Kluwer.

Kreijns, K., Kirschner, P. A., \& Jochems, W. (2003). Identifying the pitfalls for social interaction in computer supported collaborative learning environments: A review of the research. Computers in Human Behaviour, 19(3), 335-353.

Krippendorff, K. (1980). Content analysis: An introduction to its methodology. California: Sage Publications.

Leuf, B., \& Cunningham, W. (2001). The wiki way: Quick collaboration of the web. Boston: AddisonWesley.

Liebowitz, S. J., \& Margolis, S. E. (1994). Network externality: An uncommon tragedy. Retrieved April, 5, 2007, from: http://www.utdallas.edu/\%7Eliebowit/jep.html

Marton, F., \& Salijo, R. (1976a). On qualitative differences in learning: 1-outcome and process. British Journal of Educational Psychology, 46, 4-11.

Marton, F., \& Salijo, R. (1976b). On qualitative differences in learning: 2-outcome as a function of the learner's conception of the task. British Journal of Educational Psychology, 46, 115-127.

Merrill, M. D. (1991). Constructivism and instructional design. Educational Technology, May, 45-53.

Neuendorf, K. A. (2002). The content analysis guidebook. California: Sage.

Oblinger, D. G., \& Oblinger, J. L. (Eds.). (2005). Educating the Net generation. Educause. Retrieved June 18, 2007 from: http://www.educause.edu/educatingthenetgen

Pea, R. D. (1994). Seeing what we build together: Distributed multimedia learning environments for transformative communications. The Journal of the Learning Sciences, 3(3), 219-225.

Piaget, J. (1963). Origins of intelligence in children. New York: Rinehart \& Wineston.

Raman, M., Ryan, T., \& Olfman, L. (2005). Designing knowledge management systems for teaching and learning with wiki technology. Journal of Information Systems Education, 16(3), 311-321.

Reid, D. K. (1993). Another vision of "visions and revisions". Remed Special Education, 14(4), 14-16.

Resnick, L.B. (1981). Instructional psychology. Annual Review of Psychology, 32, 689-704.

Resta, P., \& Laferriere, T. (2006). Technology in support of collaborative learning. Educational Psychological Review. 19(1), 65-83.

Shuell, T. J. (1986). Cognitive conceptions of learning. Review of Educational Research, 56, 411-436.

Stahl, G. (2006). Group cognition: Computer support for building collaborative knowledge. Cambridge, MA: MIT Press.

Stephens, M. (2006). Exploring web 2.0 and libraries. Library Technology Reports, 42 (4), 8-15.

Wagner, C. (2004). WIKI: A technology for conversational knowledge management and group collaboration. Communications of the Association for Information Systems, 13, 265-289.

Wagner, C., Cheung, K. S., \& Rachael, K. F. (2006). Building semantic webs for e-government with wiki technology. Electronic Government, 3(1), 36- 55. 


\section{Biography}

Noa Aharony received her Ph.D. in 2003 from the School of Education at Bar Ilan University (Israel). Her research interests are in education for library and information science, school librarianship, educational technology, knowledge economy, marketing, and Web 2.0. Dr. Aharony has published in refereed LIS and education journals and teaches courses in information literacy, distance learning, school librarianship and knowledge management at the School of Information Science at Bar Ilan University and at Beit Berl College. 